\title{
SCIENCE AND ENGINEERING PRACTICES IN THE CONTENT OF GREEK MIDDLE SCHOOL PHYSICS TEXTBOOKS ABOUT FORCES AND MOTION
}

\author{
Margarita Papakonstantinou (D), Michael Skoumios (iD) \\ Department of Primary Education, University of the Aegean (Greece) \\ pred18009@aegean.gr,skoumios@rbodes.aegean.gr
}

Received March 2021

Accepted June 2021

\begin{abstract}
It has been argued that students' understanding of science ideas and concepts is based on their engagement in science and engineering practices. However, research studying science and engineering practices engaging in the content of school science textbooks is particularly limited. The aim of the present study is to develop a framework and investigate (through it) the level at which science and engineering practices engage in the content of Greek middle school Physics textbooks about forces and motion. The analysis was carried out on a total of 61 reports and activities on forces and motion that are included in school textbooks (student's book and lab workbook) used for teaching Physics to 13-year-old middle school students in Greece. Reports and activities were analyzed using content analysis. An assessment rubric called "Science and Engineering Practices Analytic Rubric" (SEPAR), which evaluates the level at which science and engineering practices engage in the above reports and activities, was used throughout the analysis. The analysis demonstrated the low level at which science and engineering practices engage in the analyzed content of these school textbooks. The SEPAR can be used for analyzing science instructional material. The results mean that no opportunities are provided to the students through the content of these school textbooks so that the students could use science and engineering practices and become familiar with them in order to better understand ideas and concepts about forces and motion.
\end{abstract}

Keywords - Science and engineering practices, School science textbooks, Middle school, Science education.

\section{To cite this article:}

Papakonstantinou, M., \& Skoumios, M. (2021). Science and engineering practices in the content of Greek middle school physics textbooks about forces and motion. Journal of Tecbnology and Science Education, 11(2), 457-473. https://doi.org/10.3926/jotse.1286

\section{Introduction}

Research data demonstrates that students usually fail to understand science ideas and concepts (Bransford, Brown \& Cocking, 1999; Leonard, Kalinowski \& Andrews, 2014; Schneider \& Hardy, 2013). Instead, they memorize facts and procedures, fail to connect what they are taught with everyday life and are not motivated to promote their learning (Kulgemeyer \& Schecker, 2014; National Research Council [NRC], 
2012; Organisation for Economic Co-Operation Development [OECD], 2016). This means that it is important to study the reasons why science education has not produced satisfactory learning outcomes.

The simplest version of a framework for studying the educational process includes the students, the instructional material and the teachers (Chingos \& Whitehurst, 2012). It has been underlined that research efforts into studying the educational process have largely been focused on teachers and students rather than on the instructional material (Banilower, Smith, Weiss, Malzahn, Campbell \& Weis, 2013). However, the instructional material, especially school textbooks, dominates the teaching practice, as it is particularly frequently used by the teachers. In particular, the school textbook is often the primary instructional medium used for teaching science at school (Davis, Janssen \& Van Driel, 2016; Fan \& Zhu, 2007). The school textbook directly affects students' learning while the students interact with it and indirectly affects students learning through its effect on the teachers and their instructional decisions during the teaching process (Bergqvist \& Chang Rundgren, 2017; Chiappetta \& Fillman, 2007; DiGiuseppe, 2014; Mullis, Martin, Foy \& Arora, 2012). Therefore, the learning process is to a great extent based on the school textbook both teachers and students use during teaching and learning. That is why the analysis of school textbooks has been the focus of systematic research.

Especially in recent years, it has been argued that students' understanding of science ideas and concepts is based on students' engagement in science and engineering practices (NRC, 2012). As a result, the development of such practices in students as well as the students' engagement in them is a main goal of students' science learning. "Tensions have emerged as science education researchers and practitioners have increasingly prioritized students' development of, and engagement in, science practices over students' acquisition of declarative knowledge about science concepts and processes" (Pierson, Clark \& Kelly, 2019: page 833).

Although students' engagement in science and engineering practices is considered particularly important for their science learning, research investigating the level at which such practices engage in school science textbooks is more limited (Cellitti, Likely, Moy \& Wright, 2018). Even though students' learning depends on the way teachers implement the instructional material, the design quality of instructional material plays a fundamental role in its implementation (Yang, Liu \& Liu, 2019). In this direction, it is necessary to establish frameworks through which the analysis of school textbooks is possible with regard to the practices engaged in them. Therefore, there is a serious need for conducting research focused on establishing frameworks of analysis and, through these frameworks, on investigating the engagement of science and engineering practices in the content of school science textbooks.

This study is focused on content about forces and motion that is included in middle school Physics textbooks used by 13-year-old students in Greece. Through a framework (an assessment rubric), it investigates the opportunities provided by the content of these school textbooks to the students so that the latter can become familiar with science and engineering practices. The purpose of this study is to develop a framework and investigate (through this framework) science and engineering practices engaging in the chapters of forces and motion of middle school Physics textbooks (student's book and lab workbook) used in Greece. In particular, the study aims to answer the following research question: what is the level of engagement of science and engineering practices in reports and activities on forces and motion included in Greek middle school Physics textbooks?

\section{Theoretical Background}

According to the US National Research Council, "science is not just a body of knowledge that reflects current understanding of the world; it is also a set of practices used to establish, extend, and refine that knowledge. Both elements -knowledge and practice- are essential" (NRC, 2012: page 26). Therefore, NRC has set the engagement of students in practices as a main goal of science education. The term science and engineering practices refers to the practices scientists engage in while investigating phenomena and building models and theories about the natural world, or engineers while designing and building models and systems (NGSS Lead States, 2013). The following eight science and engineering practices have 
been proposed for science education (NGSS Lead States, 2013; NRC, 2012): (a) asking questions (for science) and defining problems (for engineering), (b) developing and using models, (c) planning and carrying out investigations, (d) analyzing and interpreting data, (e) using mathematics and computational thinking, (f) constructing explanations (for science) and designing solutions (for engineering), (g) engaging in argument from evidence and (h) obtaining, evaluating, and communicating information.

Students' engagement in science and engineering practices has significant effects on both their cognitive and emotional domains. In particular, it has been argued that students' engagement in science and engineering practices could help them understand the process for developing scientific knowledge and even construct complex science ideas and concepts (Duschl, Schweingruber \& Shouse, 2007; NRC, 2012). Moreover, when students engage in science and engineering practices, they actively participate in the learning process, while their curiosity and interest are aroused more than when they simply memorize or recall information (Inkinen, Klager, Juuti, Schneider, Salmela-Aro, Krajcik et al., 2020; Krajcik, 2015; Miller, Manz, Russ, Stroupe \& Berland, 2018). Research data also demonstrates that teaching based on such practices may support students' feeling that they can successfully learn science (Mody, 2015).

\section{Literature Review}

Research focused on analyzing school science textbooks is particularly extensive. A recent literature review carried out by Vojir and Rusek (2019) studied research papers focused on analyzing school science textbooks published between 2000 and 2018. In particular, 183 research papers analyzing school science textbooks were studied. The majority of them focused on selecting and organizing the content, on teaching methods and visual images as well as on the language used in the textbooks that were studied. Over the years, the number of similar research papers increased, which proves that the analysis of school textbooks is a matter of great research interest.

Among the papers focusing on analyzing the content of school science textbooks there are also papers on inquiry processes engaging in the content of school science textbooks. More specifically, there are research papers that focus on the evaluation of the instructional efficiency of inquiry processes engaging in the content of school textbooks. This category also includes frameworks of analysis through which school textbook activities can be analyzed with regard to the inquiry skills the students are expected to develop (Germann, Haskins \& Auls, 1996; Al-Naqbi, 2010; Tamir \& Lunetta, 1981).

Other research papers focused on educational functions of inquiry processes engaging in the content of school textbooks. In this direction, Millar (2010) proposed a framework of analysis ("Practical Activity Analysis Inventory") that can be used for analyzing activities as to whether they promote in the students connections between the domain of objects and observables and the domain of ideas, while Yang and Liu (2016) proposed a different framework of analysis ("Inquiry-based Tasks Analysis Inventory") through which activities can be analyzed along four axes with regard to whether they help students understand concepts, develop inquiry process skills, understand scientific inquiries and develop higher-order thinking skills. The above framework was used for analyzing school Biology textbooks in China and revealed that only a few of their activities provided the students with adequate opportunities to understand scientific concepts and inquiry processes, while school textbooks only focused on certain inquiry process skills (Yang et al., 2019).

There are also research papers focusing on discriminating the openness levels of inquiry processes engaging in school textbook content. These papers analyze the activities of the textbooks with regard to whether the questions, the methods of the inquiry process and the solutions are provided to the students or the students are left to provide them (Bell, Smetana \& Binns, 2005; Bulunuz, Jarrett \& Martin-Hansen, 2012; Fay, Grove, Towns \& Bretz, 2007; Germann et al., 1996; Herron, 1971; Wenning, 2007).

Other research papers focused on whether inquiry processes are described by certain features, as the latter have been determined by NRC (1996), which engage in school textbook content. Dunne, Mahdi and O'Reilly (2013) analyzed primary school science textbooks of Ireland with regard to the features of 
inquiry processes and discovered that most of their activities included such features. However, the analysis of school chemistry textbooks in Turkey demonstrated that they did not include adequate features of scientific inquiry (Kahveci, 2010). Based on these features of scientific inquiry (NRC, 1996),

Aldahmash, Mansour, Alshamrani and Almohi (2016) proposed a rubric for each of these features in order to analyze high-school science textbooks of Saudi Arabia. It emerged that main features of the scientific inquiry engaged in almost half of their activities. However, certain features occurred more frequently than others, which occurred more rarely, and the inclusion of these features was "teacher-centered".

Therefore, it becomes evident that there is extensive research focusing on analyzing school science textbooks, while a substantial part of the research has focused on inquiry processes engaging in school textbook content. But, in recent years, the necessity of engaging students in science and engineering practices has been underlined, as it has been argued that the engagement of students in these practices is necessary in order to understand science ideas and concepts (NGSS Lead States, 2013). In this direction, based on a framework of analysis they developed in order to analyze online science lessons with regard to the dimensions of science and engineering practices engaging in their content, Cellitti et al. (2018) found that only certain practices engage in their activities and, more specifically, only certain of their dimensions.

Although the importance of science and engineering practices in science education has been recognized, research on analyzing printed or digital instructional material with regard to the practices engaging in its content is particularly limited. Furthermore, this research analyzed the occurrence of only certain dimensions of science and engineering practices in science lessons, but the level at which these practices engage in the instructional material, and especially in school textbooks, was not investigated. This reveals the necessity of conducting research focusing on both constructing frameworks of analysis that include the properly graduated engagement levels of these practices and analyzing school science textbooks with regard to the opportunities the students are provided with in order to engage in science and engineering practices as well as with regard to the level at which these practices engage in school textbook content.

\section{Methodology}

\subsection{Research Design}

Reports and activities on forces and motion included in Greek middle school Physics textbooks were analyzed using content analysis (Hsieh \& Shannon, 2005; Krippendorff, 2013). Content analysis is a widely spread and tested method for analyzing school textbooks (Strijbos, Martens, Prins \& Jochems, 2006) and is in line with the purpose of the present study since it allows the identification of different science and engineering practices as well as the levels at which they are involved in the sections of the content of the school textbooks selected to be analyzed.

The research process was divided into three phases. At first, reports and activities (units of analysis) on forces and motion that are included in middle school Physics textbooks were identified. Then, a framework for the analysis of the instructional material (school textbooks) was developed and, through this, the instructional material was analyzed, the data was processed, and the conclusions were drawn.

\subsection{Sample and Units of Analysis}

This study focuses on analyzing the chapters on forces and motion that are included in middle school Physics textbooks used by 13-year-old students in Greece. The Greek educational system comprises three stages. The first stage is the compulsory six-year primary school, including students aged between six and twelve years old. The second stage, the middle school (Gymnasium), covers the three following years of compulsory education, with students aged between twelve and fifteen years old. Finally, the third stage, the high school (Lyceum), covers three years of non-compulsory education, with students aged between sixteen and eighteen years old. Primary school students are taught science as a single subject, while when 
they attend the Gymnasium and the Lyceum, they are taught four distinct subjects, i.e. Physics, Chemistry, Biology and Geology.

At the beginning of each academic year, the students of each grade are provided by the Greek Ministry of Education and Religious Affairs with the school textbooks they are to be taught. There are specific textbooks for the students of each grade and all students receive the same textbooks. There is no possibility for teachers to choose the textbooks. Second grade middle school students (13 years old) are provided with the same Physics textbooks (a student's book and a lab workbook). The conceptual areas of forces and motion is prominent in the content of these textbooks and cover their greatest part.

Any conceptual unit independent of the rest text and able to make complete sense was described as unit of analysis. This means that it has a beginning and an end, while its content is relatively independent, i.e. it can be identified and separated from the other units of analysis. Sometimes the unit of analysis is identified with a subunit of the school textbook, as specified by the authors. However, there are times when the subunit is divided into separate units of analysis because differentiations can be detected in their conceptual contents. In particular, every report (text section that makes sense), every activity (problem, question) and every activity of the lab workbook was considered as a unit of analysis. The unit of analysis consists of the text part and the accompanying representations. The research sample included the units of analysis of the chapter on forces and motion of the second grade Greek middle school Physics textbooks (student's book, lab workbook). There was a total of 61 units of analysis.

\subsection{Analysis Framework}

Research on establishing frameworks that analyze instruction with regard to the science practices it includes is particularly limited. More specifically, a four-level rubric has been proposed ("Science Practices Continuum"), which evaluates the level at which teachers and students engage each science practice in science teaching (McNeill, Katsh-Singer \& Pelletier, 2015). However, this framework is mainly focused on teachers and students during the teaching process rather than on school textbooks.

For the purposes of analyzing school science textbooks with regard to the science practices engaged, the frameworks that have been used evaluate whether or not certain individual dimensions of science practices engage in school textbooks (Cellitti et al., 2018). However, they do not evaluate the levels at which these practices (as a whole and not as separate dimensions) engage in school textbooks. Moreover, the above frameworks of analysis only include science practices. They do not include engineering practices. Therefore, there is necessity of establishing a framework that examines the level at which science and engineering practices engage in the content of school science textbooks.

In the framework that was specially developed for the needs of this study, Science and Engineering Practices Analytic Rubric (SEPAR) evaluates the level at which science and engineering practices engage in the content of school textbooks (Table 1). This framework is a rubric with four levels for each practice. The established framework was based on the framework developed by McNeill et al. (2015) and on Appendix F of NGSS, and especially on its data about Grades 6-8 (NGSS Lead States, 2013). The levels differ according to the extent to which the practice engages in the units of analysis. When a unit of analysis fails to provide the students with opportunities to engage in a practice, it is classified at level 0 . The other levels (1, 2 and 3) represent increasing proficiency in practice. For example, regarding the science and engineering practice in planning and carrying out investigations, when the students are not provided with opportunities to design or conduct investigations through a unit of analysis, then this unit of analysis is classified at level 0 . When, through a unit of analysis, the students are provided with opportunities to conduct investigations but those opportunities are guided by the school textbook (i.e. the students are not let to make decisions on experimental variables or investigational methods), then this unit of analysis is classified at level 1 . Level 2 includes a unit of analysis that provides the students with opportunities to design or conduct investigations for the collection of data, while these opportunities allow the students to make decisions on experimental variables, controls and investigational methods (e.g. number of trials). Finally, level 3 includes a unit of analysis that, on the one hand, provides the students 
with opportunities to design and, on the other hand, provides the students with opportunities to conduct investigations for the collection of data, while these opportunities allow the students to make decisions on experimental variables, controls and investigational methods.

\begin{tabular}{|c|c|c|c|c|}
\hline $\begin{array}{l}\text { Science and } \\
\text { Engineering } \\
\text { Practices }\end{array}$ & Level 0 & Level 1 & Level 2 & Level 3 \\
\hline $\begin{array}{l}\text { 1. Asking } \\
\text { questions and } \\
\text { defining } \\
\text { problems }\end{array}$ & $\begin{array}{l}\text { The } \\
\text { instructional } \\
\text { material does } \\
\text { not provide the } \\
\text { students with } \\
\text { opportunities } \\
\text { to ask } \\
\text { questions or } \\
\text { define } \\
\text { problems. }\end{array}$ & $\begin{array}{l}\text { The instructional material } \\
\text { provides the students } \\
\text { with opportunities to ask } \\
\text { questions or define } \\
\text { problems. It is not } \\
\text { clarified whether the } \\
\text { questions to be asked } \\
\text { should be scientific or } \\
\text { non-scientific or whether } \\
\text { the problems to be } \\
\text { defined can be solved (by } \\
\text { using previously obtained } \\
\text { knowledge) through the } \\
\text { development of an } \\
\text { object, a tool, a process or } \\
\text { a system. }\end{array}$ & $\begin{array}{l}\text { The instructional } \\
\text { material provides the } \\
\text { students with } \\
\text { opportunities to ask } \\
\text { questions or define } \\
\text { problems. It is clarified } \\
\text { that the questions to be } \\
\text { asked should be } \\
\text { scientific, while the } \\
\text { problems to be defined } \\
\text { should be solved } \\
\text { through the } \\
\text { development of an } \\
\text { object, a tool, a process } \\
\text { or a system. It is not } \\
\text { clarified whether the } \\
\text { merits and limitations of } \\
\text { the questions to be } \\
\text { asked should be } \\
\text { evaluated or the criteria } \\
\text { for the materials, the } \\
\text { time or the cost of } \\
\text { solving the problems to } \\
\text { be defined are not } \\
\text { clarified. }\end{array}$ & $\begin{array}{l}\text { The instructional material } \\
\text { provides the students } \\
\text { with opportunities to ask } \\
\text { questions or define } \\
\text { problems. It is clarified } \\
\text { that the questions to be } \\
\text { asked should be scientific, } \\
\text { while the problems to be } \\
\text { defined should be solved } \\
\text { through the development } \\
\text { of an object, a tool, a } \\
\text { process or a system. It is } \\
\text { clarified that the merits } \\
\text { and limitations of the } \\
\text { questions to be asked } \\
\text { should be evaluated or the } \\
\text { criteria for the materials, } \\
\text { the time or the cost of } \\
\text { solving the problems to } \\
\text { be defined are clarified. }\end{array}$ \\
\hline $\begin{array}{l}\text { 2. Developing } \\
\text { and using } \\
\text { models }\end{array}$ & $\begin{array}{l}\text { The } \\
\text { instructional } \\
\text { material does } \\
\text { not provide the } \\
\text { students with } \\
\text { opportunities } \\
\text { to create or use } \\
\text { models. }\end{array}$ & $\begin{array}{l}\text { The instructional material } \\
\text { provides the students } \\
\text { with opportunities to } \\
\text { create or use models. It is } \\
\text { not clarified whether the } \\
\text { models should focus on } \\
\text { describing natural } \\
\text { phenomena or on } \\
\text { predicting and explaining } \\
\text { the natural world. It is not } \\
\text { clarified whether the } \\
\text { merits and limitations of } \\
\text { the model should be } \\
\text { evaluated. }\end{array}$ & $\begin{array}{l}\text { The instructional } \\
\text { material provides the } \\
\text { students with } \\
\text { opportunities to create } \\
\text { or use models focused } \\
\text { on predicting or } \\
\text { explaining the natural } \\
\text { world. It is not clarified } \\
\text { whether the merits and } \\
\text { limitations of the model } \\
\text { should be evaluated. }\end{array}$ & $\begin{array}{l}\text { The instructional material } \\
\text { provides the students } \\
\text { with opportunities to } \\
\text { create or use models } \\
\text { focused on predicting or } \\
\text { explaining the natural } \\
\text { world. It is clarified that } \\
\text { the merits and limitations } \\
\text { of the model should be } \\
\text { evaluated. }\end{array}$ \\
\hline $\begin{array}{l}\text { 3. Planning and } \\
\text { carrying out } \\
\text { investigations }\end{array}$ & $\begin{array}{l}\text { The } \\
\text { instructional } \\
\text { material does } \\
\text { not provide the } \\
\text { students with } \\
\text { opportunities } \\
\text { to design or } \\
\text { conduct } \\
\text { investigations. }\end{array}$ & $\begin{array}{l}\text { The instructional material } \\
\text { provides the students with } \\
\text { opportunities to conduct } \\
\text { investigations, although } \\
\text { these opportunities are } \\
\text { usually guided by the } \\
\text { instructional material. It is } \\
\text { not clarified whether } \\
\text { decisions on experimental } \\
\text { variables or the } \\
\text { investigational method } \\
\text { should be made. }\end{array}$ & $\begin{array}{l}\text { The instructional } \\
\text { material provides the } \\
\text { students with } \\
\text { opportunities to design } \\
\text { or conduct } \\
\text { investigations for data } \\
\text { collection. These } \\
\text { opportunities allow the } \\
\text { students to make } \\
\text { decisions on } \\
\text { experimental variables, } \\
\text { controls and } \\
\text { investigational methods. }\end{array}$ & $\begin{array}{l}\text { The instructional material } \\
\text { provides the students } \\
\text { with opportunities to } \\
\text { design and conduct } \\
\text { investigations for data } \\
\text { collection. These } \\
\text { opportunities allow the } \\
\text { students to make } \\
\text { decisions on experimental } \\
\text { variables, controls and } \\
\text { investigational methods. }\end{array}$ \\
\hline
\end{tabular}




\begin{tabular}{|c|c|c|c|c|}
\hline $\begin{array}{c}\text { Science and } \\
\text { Engineering } \\
\text { Practices }\end{array}$ & Level 0 & Level 1 & Level 2 & Level 3 \\
\hline $\begin{array}{l}\text { 4. Analyzing } \\
\text { and interpreting } \\
\text { data }\end{array}$ & \begin{tabular}{|l|} 
The \\
instructional \\
material does \\
not provide the \\
students with \\
opportunities \\
to analyze data. \\
The \\
instructional \\
material may \\
provide the \\
students with \\
opportunities \\
to record data \\
but not to \\
analyze it. \\
\end{tabular} & $\begin{array}{l}\text { The instructional material } \\
\text { provides the students } \\
\text { with opportunities to } \\
\text { work with data, which } \\
\text { could include organizing } \\
\text { or grouping the data. } \\
\text { However, these } \\
\text { opportunities do not } \\
\text { support the students in } \\
\text { recognizing patterns or } \\
\text { relationships in the } \\
\text { natural world. }\end{array}$ & $\begin{array}{l}\text { The instructional } \\
\text { material provides the } \\
\text { students with } \\
\text { opportunities to work } \\
\text { with data so as to } \\
\text { organize or group the } \\
\text { data in a table or a } \\
\text { graph. These } \\
\text { opportunities support } \\
\text { the students in drawing } \\
\text { conclusions from the } \\
\text { data through } \\
\text { recognizing patterns and } \\
\text { relationships in the } \\
\text { natural world. }\end{array}$ & $\begin{array}{l}\text { The instructional material } \\
\text { provides the students } \\
\text { with opportunities to } \\
\text { make decisions about } \\
\text { how they will analyze the } \\
\text { data (i.e. in a graph or a } \\
\text { table) and work with the } \\
\text { data in order to create the } \\
\text { representation. These } \\
\text { opportunities support the } \\
\text { students in drawing } \\
\text { conclusions from the data } \\
\text { through recognizing } \\
\text { patterns and relationships } \\
\text { in the natural world. }\end{array}$ \\
\hline $\begin{array}{l}\text { 5. Using } \\
\text { mathematics } \\
\text { and } \\
\text { computational } \\
\text { thinking }\end{array}$ & \begin{tabular}{|l|} 
The \\
instructional \\
material does \\
not provide the \\
students with \\
opportunities \\
to use \\
mathematical \\
skills (e.g. \\
measurements) \\
or concepts \\
(e.g. sum).
\end{tabular} & $\begin{array}{l}\text { The instructional material } \\
\text { provides the students } \\
\text { with opportunities to use } \\
\text { mathematical skills or } \\
\text { concepts, although they } \\
\text { are not connected to } \\
\text { answering a scientific } \\
\text { question. }\end{array}$ & $\begin{array}{l}\text { The instructional } \\
\text { material provides the } \\
\text { students with } \\
\text { opportunities to use } \\
\text { mathematical skills or } \\
\text { concepts that are } \\
\text { connected to answering } \\
\text { a scientific question. }\end{array}$ & $\begin{array}{l}\text { The instructional } \\
\text { material provides the } \\
\text { students with } \\
\text { opportunities to make } \\
\text { decisions about what } \\
\text { mathematical skills or } \\
\text { concepts to use. The } \\
\text { students are provided } \\
\text { with opportunities to use } \\
\text { mathematical skills or } \\
\text { concepts to answer a } \\
\text { scientific question. }\end{array}$ \\
\hline $\begin{array}{l}\text { 6. Constructing } \\
\text { explanations } \\
\text { and designing } \\
\text { solutions }\end{array}$ & $\begin{array}{l}\text { The } \\
\text { instructional } \\
\text { material does } \\
\text { not provide the } \\
\text { students with } \\
\text { opportunities } \\
\text { to construct } \\
\text { scientific } \\
\text { explanations } \\
\text { (relating to how } \\
\text { or why a } \\
\text { phenomenon } \\
\text { takes place) or } \\
\text { design } \\
\text { solutions to } \\
\text { problems. }\end{array}$ & $\begin{array}{l}\text { The instructional material } \\
\text { provides the students } \\
\text { with opportunities to } \\
\text { construct scientific } \\
\text { explanations (relating to } \\
\text { how or why a } \\
\text { phenomenon takes place) } \\
\text { without encouraging } \\
\text { them to use appropriate } \\
\text { evidence and reasonings } \\
\text { or design solutions to } \\
\text { problems, without } \\
\text { implementing scientific } \\
\text { ideas and without } \\
\text { inventing or contrasting } \\
\text { multiple solutions to a } \\
\text { problem. }\end{array}$ & $\begin{array}{l}\text { The instructional } \\
\text { material provides the } \\
\text { students with } \\
\text { opportunities to } \\
\text { construct scientific } \\
\text { explanations by } \\
\text { encouraging them to use } \\
\text { appropriate evidence in } \\
\text { order to support } \\
\text { explanations or to } \\
\text { design solutions to } \\
\text { problems by } \\
\text { implementing scientific } \\
\text { ideas, though without } \\
\text { generating and } \\
\text { comparing multiple } \\
\text { solutions to a problem } \\
\text { based on how well they } \\
\text { meet the criteria and the } \\
\text { constraints of the design } \\
\text { solution. }\end{array}$ & $\begin{array}{l}\text { The instructional material } \\
\text { provides the students } \\
\text { with opportunities to } \\
\text { construct scientific } \\
\text { explanations by } \\
\text { encouraging them to use } \\
\text { appropriate evidence and } \\
\text { reasonings in order to } \\
\text { support explanations or } \\
\text { to design solutions to } \\
\text { problems by generating } \\
\text { and comparing multiple } \\
\text { solutions to a problem } \\
\text { based on how well they } \\
\text { meet the criteria and the } \\
\text { constraints of the design } \\
\text { solution }\end{array}$ \\
\hline
\end{tabular}




\begin{tabular}{|c|c|c|c|c|}
\hline $\begin{array}{c}\text { Science and } \\
\text { Engineering } \\
\text { Practices }\end{array}$ & Level 0 & Level 1 & Level 2 & Level 3 \\
\hline $\begin{array}{l}\text { 7. Engaging in } \\
\text { argument from } \\
\text { evidence }\end{array}$ & $\begin{array}{l}\text { The } \\
\text { instructional } \\
\text { material does } \\
\text { not provide the } \\
\text { students with } \\
\text { opportunities } \\
\text { to engage in } \\
\text { argumentation. }\end{array}$ & $\begin{array}{l}\text { The instructional material } \\
\text { provides the students } \\
\text { with opportunities to } \\
\text { engage in argumentation } \\
\text { by encouraging them to } \\
\text { support their claims with } \\
\text { evidence or reasoning. } \\
\text { However, their discourse } \\
\text { is mainly guided by the } \\
\text { instructional material. }\end{array}$ & $\begin{array}{l}\text { The instructional } \\
\text { material provides the } \\
\text { students with } \\
\text { opportunities to engage } \\
\text { in argumentation that is } \\
\text { allowed to be guided by } \\
\text { the students. It should } \\
\text { be clarified that their } \\
\text { discourse should include } \\
\text { evidence and reasoning } \\
\text { in order to support their } \\
\text { claims. It is not clarified } \\
\text { whether the students } \\
\text { should engage in } \\
\text { criticism of the others' } \\
\text { ideas. }\end{array}$ & $\begin{array}{l}\text { The instructional material } \\
\text { provides the students } \\
\text { with opportunities to } \\
\text { engage in argumentation } \\
\text { that is allowed to be } \\
\text { guided by the students. It } \\
\text { should be clarified that } \\
\text { their discourse should } \\
\text { include evidence and } \\
\text { reasoning (which connect } \\
\text { their evidence with their } \\
\text { claims) and judgments on } \\
\text { the opposing arguments } \\
\text { through which they } \\
\text { support and question } \\
\text { their own and the others' } \\
\text { ideas. }\end{array}$ \\
\hline $\begin{array}{l}\text { 8. Obtaining, } \\
\text { evaluating and } \\
\text { communicating } \\
\text { information }\end{array}$ & $\begin{array}{l}\text { The } \\
\text { instructional } \\
\text { material does } \\
\text { not provide the } \\
\text { students with } \\
\text { opportunities } \\
\text { to read text for } \\
\text { scientific } \\
\text { information. }\end{array}$ & $\begin{array}{l}\text { The instructional material } \\
\text { provides the students } \\
\text { with opportunities to } \\
\text { obtain scientific } \\
\text { information from texts, } \\
\text { though without evaluating } \\
\text { this information. They are } \\
\text { not encouraged to } \\
\text { contrast or combine } \\
\text { information from } \\
\text { multiple texts by } \\
\text { examining the strengths } \\
\text { of the information and } \\
\text { their sources. }\end{array}$ & $\begin{array}{l}\text { The instructional } \\
\text { material provides the } \\
\text { students with } \\
\text { opportunities to read } \\
\text { and evaluate texts in } \\
\text { order to obtain scientific } \\
\text { information. They are } \\
\text { not encouraged to } \\
\text { contrast or combine } \\
\text { information from } \\
\text { multiple texts by } \\
\text { examining the strengths } \\
\text { of the information and } \\
\text { their sources. }\end{array}$ & $\begin{array}{l}\text { The instructional material } \\
\text { provides the students } \\
\text { with opportunities to read } \\
\text { and evaluate texts in order } \\
\text { to obtain scientific } \\
\text { information. They are } \\
\text { encouraged to contrast or } \\
\text { combine information } \\
\text { from multiple texts by } \\
\text { examining the strengths } \\
\text { of the information and } \\
\text { their sources. }\end{array}$ \\
\hline
\end{tabular}

Table 1. Science and Engineering Practices Analytic Rubric (SEPAR)

\subsection{Data Analysis}

The units of analysis were analyzed with regard to the levels of engagement of each of the eight science and engineering practices, on the basis of the SEPAR that was developed.

In order to ensure the reliability of content analysis, the latter was carried out by two independently working science education researchers. They codified every unit of analysis by describing the level' of each practice engaged in it and then calculated the degree of agreement of their results by using Cohen's kappa coefficient (Cohen, 1990). Kappa (k) coefficient in all eight practices was higher than 0.74 (0.75 for practices 2 and 6 , 0.94 for the other practices). Any disagreements between the researchers were resolved through discussion.

Before the analysis started for the contents of the 61 units of analysis, a pilot analysis was carried out on a small sample of units of analysis of school textbooks in order to determine the levels of all eight practices. The pilot research was necessary for the researchers to get acquainted with the rubric and to discuss whether they needed to make any corrections in the analysis process. After analyzing the 61 units of analysis, the frequencies and percentages of the levels at which the practices engage in the reports and activities analyzed were identified.

Below are three examples of activities from Greek middle school Physics textbooks followed by their analyses according to SEPAR. 


\section{Example 1}

"Circle the letter or the letters that correspond to the correct answers:

a) action and reaction are equal and act in opposite directions,

b) action and reaction are exerted on the same body,

c) every action is always related to a reaction,

d) the speeds of two bodies on which action and reaction are respectively exerted are varied in the same way."

\section{Analysis of Example 1}

The above activity does not provide the students with the opportunities to ask questions, develop and use models, design investigations, analyze data, use mathematical concepts, construct explanations, engage in argument or study a text in order to extract information. As a result, through this activity, the students do not engage in any of the eight science and engineering practices. It is therefore concluded that the level at which the practices engage in this activity, in accordance with SEPAR, is level 0.

\section{Example 2}

"A rubber lies stationary on your desk. Draw the forces acting on the rubber and state by which object each of them comes from. Classify them into contact and non contact forces. Repeat the same steps while moving the rubber in one direction along the page of your notebook in order to erase a sentence."

\section{Analysis of Example 2}

The above activity engages the practice that is related to the development and use of models. In particular, through this activity, the students are provided with the opportunity to use models (by drawing forces represented as vectors). However, the students are not asked to predict and explain phenomena through the representation of forces. Also, the students are not asked to evaluate the model and its merits and limitations on representing forces in the specific activity. Hence, according to SEPAR, the practice involving the use of models engages in this activity at level 1. Furthermore, this activity does not provide the students with opportunities to engage in any of the seven other science and engineering practices. As a result, the remaining seven practices engage in this activity at level 0 .

\section{Example 3}

"With the help of a rope a constant horizontal force is exerted on a box that moves in a straight line with constant velocity on a rough horizontal floor. If the force of weight exerted on the box is $200 \mathrm{~N}$ and the force of friction is $80 \mathrm{~N}$. (a) Draw all the forces exerted on the box, (b) Calculate the magnitude of the force exerted by the rope and the force exerted by the ground."

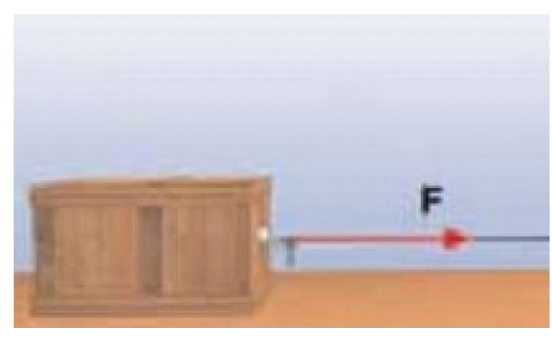

\section{Analysis of Example 3}

The above activity engages the practice that is related to the development and use of models. Through this activity, the students are provided with the opportunity to use models (by drawing forces represented as vectors). Furthermore, the students are asked to predict and explain phenomena (they calculate the forces after taking into account both Newton's first law and the constant velocity of the 
box in the straight line) through the representation of forces. However, the students are not asked to evaluate the model and its merits and limitations on representing forces in the specific activity. Hence, according to SEPAR, the practice involving the use of models engages in this activity at level 2. Furthermore, this activity provides opportunities to use mathematics (they should use vector addition in order to calculate the forces) but they don't make decisions about what mathematical skills or concepts to use and they are not using mathematical skills or concepts to answer a scientific question. Hence, according to SEPAR, the practice involving the use of mathematics and computational thinking engages in this activity at level 1 . Finally, this activity does not provide the students with opportunities to engage in any of the other six science and engineering practices. As a result, the remaining six practices engage in this activity at level 0 .

\section{Results and Discussion}

Data analysis identified the levels of the practices involved in the content about forces and motion that is included in the middle school science textbooks that were studied. Table 2 shows the frequencies and percentages of the levels of science and engineering practices engaging in all 61 units of analysis.

Figure 1 shows the percentages of the levels of science and engineering practices engaging in all 61 units of analysis.

The practice of asking questions and defining problems seems to be completely absent from the content of school science textbooks about forces and motion that was analyzed. As a result, the specific textbooks do not provide the students with opportunities to ask questions, realize the difference between scientific and non-scientific questions, and evaluate the merits and limitations of scientific questions. Furthermore, they do not provide the students with opportunities to define problems that can be solved (using previously obtained knowledge) through the development of an object, a tool, a process or a system, as well as to define the criteria related to the materials, the time or the cost of solving the problems to be defined. However, it has been underlined that when the students themselves ask questions and define problems, their original conceptions may be activated and they can be helped in processing their knowledge (Chin \& Osborne, 2008). Moreover, when students ask questions, they take the first step towards designing and conducting scientific investigations (Kahveci, 2010; Millar, Osborne \& Nott, 1998). In addition, when students are provided with opportunities to ask questions or define problems, their active engagement in the teaching process may be increased, as demonstrated by empirical data (Reiser, Novak, Tipton \& Adams, 2017).

\begin{tabular}{|c|c|c|c|c|c|c|c|c|}
\hline \multirow{2}{*}{$\begin{array}{l}\text { Science and Engineering } \\
\text { Practices }\end{array}$} & \multicolumn{2}{|c|}{ Level 0} & \multicolumn{2}{|c|}{ Level 1} & \multicolumn{2}{|c|}{ Level 2} & \multicolumn{2}{|c|}{ Level 3} \\
\hline & f & $\%$ & f & $\%$ & f & $\%$ & f & $\%$ \\
\hline $\begin{array}{l}\text { Asking questions and defining } \\
\text { problems }\end{array}$ & 61 & 100 & 0 & 0 & 0 & 0 & 0 & 0 \\
\hline Developing and using models & 41 & 67.2 & 18 & 29.5 & 2 & 3.3 & 0 & 0 \\
\hline $\begin{array}{l}\text { Planning and carrying out } \\
\text { investigations }\end{array}$ & 59 & 96.7 & 2 & 3.3 & 0 & 0 & 0 & 0 \\
\hline Analyzing and interpreting data & 59 & 96.7 & 2 & 3.3 & 0 & 0 & 0 & 0 \\
\hline $\begin{array}{l}\text { Using mathematics and } \\
\text { computational thinking }\end{array}$ & 51 & 83.6 & 10 & 16.4 & 0 & 0 & 0 & 0 \\
\hline $\begin{array}{l}\text { Constructing explanations and } \\
\text { designing solutions }\end{array}$ & 44 & 72.1 & 15 & 24.6 & 2 & 3.3 & 0 & 0 \\
\hline $\begin{array}{l}\text { Engaging in argument from } \\
\text { evidence }\end{array}$ & 58 & 95.1 & 3 & 4.9 & 0 & 0 & 0 & 0 \\
\hline $\begin{array}{l}\text { Obtaining, evaluating and } \\
\text { communicating information }\end{array}$ & 59 & 96.7 & 2 & 3.3 & 0 & 0 & 0 & 0 \\
\hline
\end{tabular}

Table 2. Frequencies and Percentages of Practice Levels in Reports and Activities of Greek Middle School Science Textbooks 


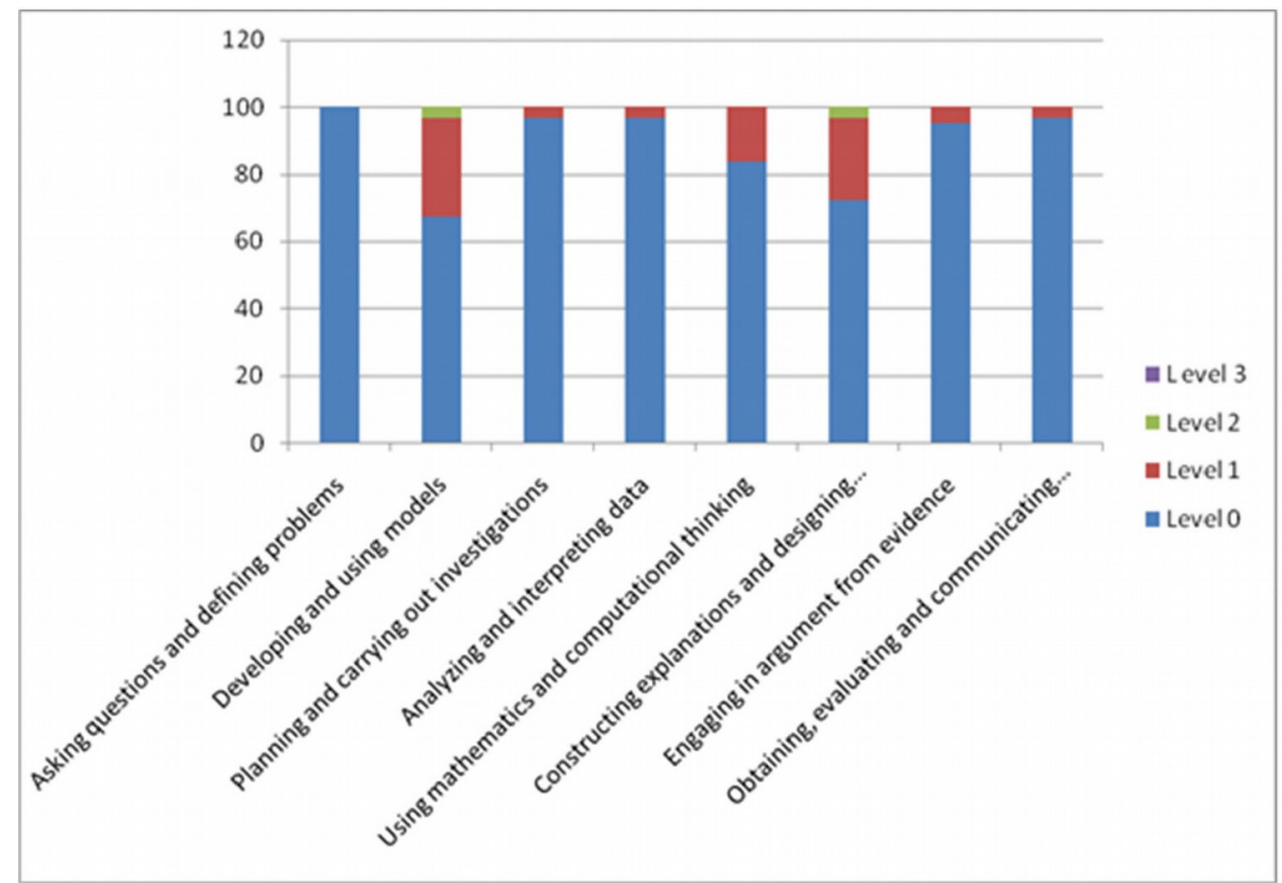

Figure 1. Percentages of Practice Levels in Reports and Activities of Greek Middle School Science Textbooks

Regarding the practice of developing and using models, it was found that there is a small number of units of analysis providing the students with opportunities to use models that aim to describe natural phenomena, while the students are rarely asked to provide predictions and explanations based on these models. Also, there were no units of analysis providing the students with opportunities to develop their own models. However, the development and use of models by the students as well as their familiarization with both the accompanying rules and their operation can contribute to understanding the phenomena for which these models have been developed (Ainsworth, Prain \& Tytler, 2011). Furthermore, the use of models may help the students in asking scientific questions, constructing explanations, making predictions and communicating their ideas (Nersessian, 2008; Schwarz, Reiser, Davis, Kenyon, Achér, Fortus et al., 2009). In addition, developing models could arouse students' interest in the lessons. As a rule, during the lessons that follow the traditional teaching approach, the students are introduced to models, but they are not provided with the opportunity to develop models. Research data demonstrates that the development of models by the students themselves contributes to their active participation in the learning process (Inkinen et al., 2020).

Practices related to designing and conducting investigations as well as analyzing and interpreting data engage in a very small number of units of analysis. However, even in these cases, the engagement of the students is guided by the textbook. In particular, when students conduct investigations in these units of analysis, they do not decide on the experimental variables or the investigational method (e.g. number of tests). Moreover, when the students work on data, they are rarely provided with the opportunity to recognize patterns within the data. Nevertheless, it has already been pointed out that understanding science ideas and concepts requires the engagement of students in the stages and the progress of scientific investigation (Mercer, Dawes, Wegerif \& Sams, 2004; OECD, 2013). Besides, this practice is considered necessary for understanding the nature of science (NRC, 2012; Pearson, Moje \& Greenleaf, 2010), develop students' ability to produce justified explanations (NRC, 2012) and arouse students' interest in science lessons (Duschl \& Bybee, 2014).

Regarding the practice of using mathematics and computational thinking, it was found that rarely does the content of school textbooks analyzed provide the students with the opportunity to use their mathematical skills or concepts. However, Orton and Roper (2000) have stressed that the use of mathematics and computational thinking may contribute to a deeper understanding of science ideas and concepts. 
The practice of constructing explanations and designing solutions can be found in a number of reports and activities of the textbooks. But even in these cases, rarely are the students encouraged to use evidence and reasonings. Still, the construction of explanations constitutes an essential element of students' science learning (NRC, 2012). In other words, the process of constructing scientific explanations and designing solutions may contribute to a deeper understanding of the content of science and the nature of science by the students (Sandoval \& Reiser, 2004).

The practice of engaging in argument based on evidence occurs in only a small number of reports and activities of the school textbooks analyzed. There were no activities engaging the students in argumentation guided by themselves so that they could assess their own and their schoolmates' explanations. Nevertheless, the engagement in argument based on evidence is considered an essential element of students' science learning (NRC, 2012). The engagement in argument is necessary not only for those who intend to be actively involved in a scientific field but for every citizen as well. Citizens are necessary to evaluate scientific data they find on the Internet or in newspapers and journals in written form, or verbal data coming from television or radio broadcasts (McNeill \& Krajcik, 2009). They should have developed the ability to evaluate arguments, determine whether their claims are based on evidence or whether the reasonings included are adequately justified. Furthermore, engaging in argument may help the students better understand science content (Pimvichai, Yuenyong \& Buaraphan, 2019; Sandoval \& Reiser, 2004).

Also, rarely are the students provided with the opportunity to obtain scientific information from "additional" texts, while they are not asked to evaluate this information or to compare or combine information from multiple texts by examining the strengths of this information and its sources. However, the above processes contribute to understanding science content and developing critical thinking (Pearson et al., 2010).

\section{Conclusions}

The present study intended to investigate the level at which science and engineering practices engage in reports and activities on forces and motion included in Greek middle school Physics textbooks. This study demonstrated that the majority of reports and activities included in the middle school Physics textbook's chapter on forces do not provide the students with enough opportunities to engage in science and engineering practices. There is only a limited number of reports and activities that provide the students with opportunities to engage in practices, although the latter are guided by the textbook and the students are not allowed to take initiatives and, therefore, they do not become thoroughly familiar with science and engineering practices. There are almost no reports or activities through which the students are provided with both opportunities to engage in science and engineering practices and initiative to make decisions. The lack of engaged science and engineering practices from the largest part of the content of school textbooks analyzed possibly does not facilitate the students to understand ideas and concepts about the conceptual area of forces and become familiar with these practices.

The results of the present paper demonstrate that the content of the school textbooks analyzed should by revised. On the one hand, all science and engineering practices should engage in their content, while, on the other hand, the level at which these practices engage should be increased. However, additional research is required so that the efficiency of the activities that deeply engage these practices can further be investigated. It should also be noted that revising such activities requires experienced teachers who can properly implement them.

In this paper, a framework (SEPAR) was created for studying the level at which science and engineering practices engage in the content of school textbooks. The proposed SEPAR framework could be used in the fields of teaching practice and research. In the field of teaching practice, the SEPAR framework can be used by the teachers for analyzing both the instructional material they are provided with and the additional instructional material (printed or digital) they seek and find in other sources. Helped by this framework, the teachers can find out whether the goals they have set regarding practices are attainable 
through the instructional material they are provided with. Moreover, with the use of this framework, teachers can modify the activities of the instructional material. In the field of research, the SEPAR framework can be used by researchers for analyzing the instructional material used in science education by primary and secondary education schools, but also for analyzing new instructional material that will be produced in order to address the weaknesses of the current instructional material.

This paper focused on investigating the practices engaging in a specific chapter of middle school science textbooks. In order to obtain a more complete picture of the practices in which the students engage, it is necessary to analyze all chapters of primary and secondary school science textbooks used in the Greek educational system. Furthermore, in terms of research, it would be really interesting to analyze school textbooks of the same conceptual area (i.e. forces and motion) used in other countries, and contrast the results.

It should also be underlined that the present paper focused only on analyzing the content of school textbooks rather than implementing them within the school framework. Further research is required in order to systematically study the effect of using science and engineering practices by implementing the school textbooks on the students.

In addition, further research is required so that to produce instructional material based on more deeply engaging science and engineering practices and to study the effect of its implementation on both familiarizing the students with the use of science and engineering practices and on making science ideas and concepts understandable by the students.

\section{Declaration of Conflicting Interests}

The authors declared no potential conflicts of interest with respect to the research, authorship, and/or publication of this article.

\section{Funding}

The authors received no financial support for the research, authorship, and/or publication of this article.

\section{References}

Ainsworth, S., Prain, V., \& Tytler, R. (2011). Drawing to learn in science. Science, 333(6046), 1096-1097. https://doi.org/10.1126/science.1204153

Aldahmash, A.H., Mansour, N.S., Alshamrani, S.M., \& Almohi, S. (2016). An analysis of activities in Saudi Arabian middle school science textbooks and workbooks for the inclusion of essential features of inquiry. Research in Science Education, 46(6), 879-900. https://doi.org/10.1007/s11165-015-9485-7

Al-Naqbi, A.K. (2010). The degree to which UAE primary science workbooks promote scientific inquiry. Research in Science \& Technological Education, 28(3), 227-247. https://doi.org/10.1080/02635143.2010.506316

Banilower, E.R., Smith, P.S., Weiss, I.R., Malzahn, K.A., Campbell, K.M., \& Weis, A.M. (2013). Report of the 2012 National Survey of Science and Mathematics Education. Chapel Hill, NC: Horizon Research, Inc. http://www.horizon-research.com/2012nssme/research-products/reports/technical-report/

Bell, R.L., Smetana, L., \& Binns, I. (2005). Simplifying inquiry instruction: Assessing the inquiry level of classroom activities. The Science Teacher, 72(7), 30-33. http://www.nsta.org/store/product detail.aspx?id=10.2505/4/tst05 $072 \quad 07 \quad 30$

Bergqvist, A., \& Chang Rundgren, S. (2017). The influence of textbooks on teachers' knowledge of chemical bonding representations relative to students' difficulties understanding. Research in Science and Technological Education, 35(2), 215-237. https://doi.org/10.1080/02635143.2017.1295934 
Bransford, J.D., Brown, A.L., \& Cocking, R.R. (1999). How people learn: Brain, mind, experience, and school. National Academy Press.

Bulunuz, M., Jarrett, O.S., \& Martin-Hansen, L. (2012). Level of inquiry as motivator in an inquiry methods course for Preservice elementary teachers. School Science and Mathematics, 112(6), 330-339. https://doi.org/10.1007/s11165-015-9485-7

Cellitti, J., Likely, R., Moy, M.K., \& Wright, C.G. (2018). A Content Analysis of NGSS Science and Engineering Practices in K-5 Curricula. Paper presented at 2018 ASEE Annual Conference and Exposition, Salt Lake City, Utah. https://peer.asee.org/29667

Chiappetta, E.L., \& Fillman, D.A. (2007). Analysis of five high school biology textbooks used in the United States for inclusion of the nature of science. International Journal of Science Education, 29(15), 1847-1868. https://doi.org/10.1080/09500690601159407

Chin, C., \& Osborne, J. (2008). Students' questions: A potential resource for teaching and learning science. Studies in Science Education, 44(1), 1-39. https://doi.org/10.1080/03057260701828101

Chingos, M.M., \& Whitehurst, G.J. (2012, April). Choosing blindly: Instructional materials, teacher effectiveness, and the common core. https://www.brookings.edu/wpcontent/uploads/2016/06/0410 curriculum chingos whitehurst.pdf

Cohen, J. (1990). Things I have learned (so far). American Psychologist, 45(12), 1304-1312. https://doi.org/10.1037/0003-066x.45.12.1304

Davis, E.A., Janssen, F.J., \& Van Driel, J.H. (2016). Teachers and science curriculum materials: Where we are and where we need to go. Studies in Science Education, 52(2), 127-160. https://doi.org/10.1080/03057267.2016.1161701

DiGiuseppe, M. (2014). Representing nature of science in a science textbook: Exploring author-editor-publisher interactions. International Journal of Science Education, 36(7), 1061-1082. https://doi.org/10.1080/09500693.2013.840405

Dunne, J., Mahdi, A.E., \& O'Reilly, J. (2013). Investigating the potential of Irish primary school textbooks in supporting inquiry-based science education (IBSE). International Journal of Science Education, 35(9), 1513-1532. https://doi.org/10.1080/09500693.2013.779047

Duschl, R.A., \& Bybee, R.W. (2014). Planning and carrying out investigations: An entry to learning and to teacher professional development around NGSS science and engineering practices. International Journal of STEM Education, 1(12), 1-9. https://doi.org/10.1186/s40594-014-0012-6

Duschl, R., Schweingruber, H., \& Shouse, A. (2007). Taking science to school: Learning and teaching science in grades K-8. Washington DC: The national Academies Press. https://www.nsf.gov/attachments/117803/public/2c--Taking Science to School.pdf

Fay, M.E., Grove, N.P., Towns, M.H., \& Bretz, S.L. (2007). A rubric to characterize inquiry in the undergraduate chemistry laboratory. Chemistry Education Research and Practice, 8(2), 212-219. http://pubs.rsc.org/en/content/articlepdf/2007/RP/B6RP90031C https://doi.org/10.1039/B6RP90031C

Fan, L., \& Zhu, Y. (2007). Representation of problem-solving procedures: A comparative look at China, Singapore, and US mathematics textbooks. Educational Studies in Mathematics, 66(1), 61-75. https://doi.org/10.1007/s10649-006-9069-6

Germann, P.J., Haskins, S., \& Auls, S. (1996). Analysis of nine high school biology laboratory manuals: Promoting scientific inquiry. Journal of Research in Science Teaching, 33(5), 475-499. https:/ / doi.org/10.1002/ (SICI)1098-2736(199605)33:5\%3C475::AID-TEA2\%3E3.0.CO;2-O 
Herron, M.D. (1971). The nature of scientific enquiry. The School Review, 79(2), 171-212. http://www.jstor.org/stable/1084259?seq=1\#page scan tab contents https://doi.org/10.1086/442968

Hsieh, H., \& Shannon, S.E. (2005). Three approaches to qualitative content analysis. Qualitative Health Research, 15(9), 1277-1288. https://doi.org/10.1177/1049732305276687

Inkinen, J., Klager, C., Juuti, K., Schneider, B., Salmela-Aro, K., Krajcik, J., et al. (2020). High school students' situational engagement associated with scientific practices in designed science learning situations. Science Education, 104(4), 667-692. https://doi.org/10.1002/sce.21570

Kahveci, A. (2010). Quantitative analysis of science and chemistry textbooks for indicators of reform: A complementary perspective. International Journal of Science Education, 32(11), 1495-1519. https://doi.org/10.1080/09500690903127649

Krajcik, J. (2015). Three-dimensional instruction: Using a new type of teaching in the science classroom. The Science Teacher, 82(8), 50-52. https://doi.org/10.2505/4/tst15_082_08_50

Krippendorff, K. (2013). Content Analysis. An Introduction to Its Methodology (3rd ed.). California, CA: Sage Publications.

Kulgemeyer, C., \& Schecker, H. (2014). Research on educational standards in German science education - Towards a model of student competences. EURASIA Journal of Mathematics, Science and Technology Education, 10(4), 257-269. https://doi.org/10.12973/eurasia.2014.1081a

Leonard, M.J., Kalinowski, S.T., \& Andrews, T.C. (2014). Misconceptions yesterday, today, and tomorrow. CBE_Life Sciences Education, 13(2), 179-186. https://doi.org/10.1187/cbe.13-12-0244

McNeill, K.L., \& Krajcik, J. (2009). Synergy between teacher practices and curricular scaffolds to support students in using domain-specific and domain-general knowledge in writing arguments to explain phenomena. Journal of the Learning Sciences, 18(3), 416-460. https://doi.org/10.1080/10508400903013488

McNeill, K., Katsh-Singer, R., \& Pelletier, P. (2015). Assessing science practices: Moving your class along a continuum. Science Scope, 39(4), 21-28. https://doi.org/10.2505/4/ss15_039_04_21

Mercer, N., Dawes, L., Wegerif, R., \& Sams, C. (2004). Reasoning as a scientist: Ways of helping children to use language to learn science. British Educational Research Journal, 30(3), 359-377. https://doi.org/10.1080/01411920410001689689

Millar, R., Osborne, J., \& Nott, M. (1998). Science education for the future. School Science Review, 80(291), $19-25$.

Millar, R. (2010). Analysing practical activities to assess and improve effectiveness. Hatfield: Association for Science Education.

https://www.researchgate.net/publication/264889206 Analysing practical science activities to assess and impr ove their effectiveness

Miller, E., Manz, E., Russ, R., Stroupe, D., \& Berland, L. (2018). Addressing the epistemic elephant in the room: Epistemic agency and the next generation science standards. Journal of Research in Science Teaching, 55(7), 1053-1075. https://doi.org/10.1002/tea.21459

Mody, C.C. (2015). Scientific practice and science education. Science Education, 99(6), 1026-1032. https://doi.org/10.1002/sce.21190

Mullis, I.V.S., Martin, M.O., Foy, P., \& Arora, A. (2012). The TIMSS 2011 International Results in Mathematics. Chestnut Hill, MA: TIMSS \& PIRLS International Study Center, Boston College. https://timssandpirls.bc.edu/timss2011/international-results-mathematics.html 
National Research Council (NRC) (1996). National Science Education Standards. Washington, DC: The National Academies Press. https://doi.org/10.17226/4962

National Research Council (NRC) (2012). A framework for K-12 science education: Practices, crosscutting concepts, and core ideas. Washington, DC: The National Academies Press. https://doi.org/10.17226/13165

Nersessian, N. (2008). Inquiry: How science works: Model-based reasoning in scientific practice. In Duschl, R.A., \& Grandy, R.E. (Eds.), Teacbing Scientific Inquiry: Recommendations for Research and Implementation (57-79). Rotterdam: Sense Publishers. https://doi.org/10.1163/9789460911453_005

NGSS Lead States (2013). Next Generation Science Standards: For States, By States. Washington, DC: The National Academies Press. https://doi.org/10.17226/18290

Organisation for Economic Co-operation and Development (OECD) (2013). PIS A 2012 Assessment and Analytical Framework: Mathematics, Reading, Science, Problem Solving and Financial Literacy. Paris, France: OECD Publishing. https://dx.doi.org/10.1787/9789264190511-en

Organisation for Economic Co-operation and Development (OECD) (2016). PIS A 2015 results: Excellence and equity in education (I). Paris, France: OECD Publishing. https://doi.org/10.1787/9789264266490-en

Orton, T., \& Roper, T. (2000). Science and mathematics: A relationship in need of counselling? Studies in Science Education, 35(1), 123-153. https://doi.org/10.1080/03057260008560157

Pearson, P.D., Moje, E., \& Greenleaf, C. (2010). Literacy and science: Each in the service of the other. Science, 328(5977), 459-463. https://doi.org/10.1126/science.1182595

Pierson, A.E., Clark, D.B., \& Kelly, G.J. (2019). Learning progressions and science practices. Science \& Education, 28(8), 833-841. https://doi.org/10.1007/s11191-019-00070-0

Pimvichai, J., Yuenyong, C., \& Buaraphan, K. (2019). Development of grade 10 students' scientific argumentation through the science-technology-society learning unit on work and energy. Journal of Technology and Science Education, 9(3), 428-441. https://doi.org/10.3926/jotse.527

Reiser, B.J., Novak, M., Tipton, K., \& Adams, L. (2017). Asking questions. In Schwarz, C.V., Passmore, C., \& Reiser, B.J. (Eds.), Helping students make sense of the world using next generation science and engineering practices (87-108). Arlington, VA: National Science Teachers Associations Press.

Sandoval, W.A., \& Reiser, B.J. (2004). Explanation-driven inquiry: Integrating conceptual and epistemic scaffolds for scientific inquiry. Science Education, 88(3), 345-372. https://doi.org/10.1002/sce.10130

Schneider, M., \& Hardy, I. (2013). Profiles of inconsistent knowledge in children's pathways of conceptual change. Developmental Psychology, 49(9), 1639-1649. https://doi.org/10.1037/a0030976

Schwarz, C.V., Reiser, B.J., Davis, E.A., Kenyon, L., Achér, A., Fortus, D., et al. (2009). Developing a learning progression for scientific modeling: Making scientific modeling accessible and meaningful for learners. Journal of Research in Science Teaching, 46(6), 632-654. https://doi.org/10.1002/tea.20311

Strijbos, J., Martens, R.L., Prins, F.J., \& Jochems, W.M. (2006). Content analysis: What are they talking about? Computers \& Education, 46(1), 29-48. https://doi.org/10.1016/j.compedu.2005.04.002

Tamir, P., \& Lunetta, V.N. (1981). Inquiry-related tasks in high school science laboratory handbooks. Science Education, 65(5), 477-484. https://doi.org/10.1002/sce.3730650503

Vojiŕ, K., \& Rusek, M. (2019). Science education textbook research trends: A systematic literature review. International Journal of Science Education, 41(11), 1496-1516. https://doi.org/10.1080/09500693.2019.1613584

Wenning, C.J. (2007). Assessing inquiry skills as a component of scientific literacy. Journal of Physics Teacher Education Online, 4(2), 21-24. http://www2.phy.ilstu.edu/pte/publications/assessing ScInq.pdf 
Yang, W., \& Liu, E. (2016). Development and validation of an instrument for evaluating inquiry-based tasks in science textbooks. International Journal of Science Education, 38(18), 2688-2711.

https://doi.org/10.1080/09500693.2016.1258499

Yang, W., Liu, C., \& Liu, E. (2019). Content analysis of inquiry-based tasks in high school biology textbooks in Mainland China. International Journal of Science Education, 41(6), 827-845.

https://doi.org/10.1080/09500693.2019.1584418

Published by OmniaScience (www.omniascience.com)

Journal of Technology and Science Education, 2021 (www.jotse.org)

\section{(c) (1) (3)}

Article's contents are provided on an Attribution-Non Commercial 4.0 Creative commons International License. Readers are allowed to copy, distribute and communicate article's contents, provided the author's and JOTSE journal's names are included. It must not be used for commercial purposes. To see the complete licence contents, please visit https://creativecommons.org/licenses/by-nc/4.0/. 